\title{
RESOURCES AND COMMUNICATIONS OPTIMALIZATION IN EDUCATIONAL MARKETING STRATEGY
}

\author{
Noor Fuadiyah Zuhaeda ${ }^{1}$ \\ ${ }^{1}$ Universitas Pendidikan Indonesia \\ nfuadiyahz@gmail.com
}

\begin{abstract}
In the era of globalization, adopting the concept of business marketing to face competition among educational institutions is something that cannot be avoided. The public demand for high-quality education, satisfactory customer service, and school's resources become the basis of consideration for the educational institution in determining its marketing strategy. Optimal educational resources management and institution's ability to communicate with customers and communities are the keys to effectively implement educational marketing strategies. The purpose of this paper using literature review methodology is to obtain a thorough understanding of resource optimization in education marketing strategies as an effort to increase customer and maintain customer loyalty.
\end{abstract}

Keywords: educational resources, educational communication, educational marketing strategy

\section{INTRODUCTION}

The development of science, technology, and globalization put all aspects of life to continue to grow and competition becomes unavoidable. No exception to the world of education, where the demands of society for high-quality education make educational institutions strive to improve themselves to be the best and worthy to be chosen by society [1]. In addition, the number of high-quality educational institutions and the presence of new educational institutions has brought changes in the competition map of education customer's enthusiasts and loyalties.

Improving and maintaining customer loyalty through high-quality education management and service will produce graduates who are qualified and have competitiveness. Effective and efficient resource management supported by effective educational communication will make it easier for education institutions to implement their marketing strategies. Appropriate, effective, and efficient of educational communication processes that take place within the school community will facilitate an easier continuity of teaching and learning activities. Meanwhile, for external scope, communication will help facilitate the process of delivering information about school's achievement to the community, getting input from customers and community, and 
establishing, managing, and developing networks in form of partnership with the community [1].

These phenomena require educational institutions to optimize the resources of educational institutions and make effective communication in determining and implementing the appropriate marketing strategies in an effort to increase customers and maintain customer loyalty of educational institutions. Thus, these educational institutions will be able to continue to grow, able to survive, and highly competitive in the era of globalization.

\section{DISCUSSION}

In determining a strategy, there are several things to consider such as the supporting and constraining factors for the organization to grow and develop. In determining the marketing strategy for the educational institution, both factors are considered[6]. Some of the supporting factors to be considered are the resources that are owned and what communication form used to convey 'the selling value' of the educational institution, so it would appeal, cultivate interest, increase satisfaction, and maintain customer loyalty.

\section{Educational Resources}

Educational institutions, especially schools have resources that can be used and utilized in an effort to support education management. Resources are consisting of human resources, biological natural resources, non-living natural resources, and artificial resources (Article 1 paragraph 5 of Law of The Republic of Indonesia No. 4 of 1982)[2]. Another term mentions that resources are a potential value possessed by a certain material or element in life. Resources may be physical or non-physical, some may change or remain fixed. According to the MBS Team of Bandung (2001) in an article written by Hermawan, R (2010, p.1) stated that the educational resources are as follows[3]:

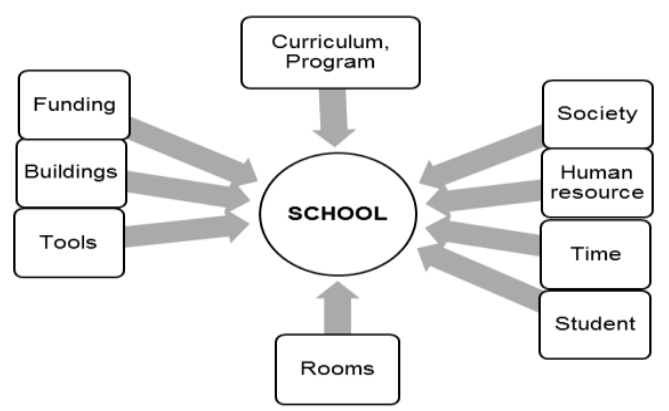

Figure 1.Education resources at school

The educational resources mentioned above can be grouped into:

1. Non-human resources, which include school programs, curriculum, and others.

A good education process is organized into a school program School programs include determining school vision, mission, goals, and targets; also strategic decision making as a well-developed way to overcome challenges and seize opportunities. The curriculum is structured as a learning guide which refers to the 
achievement of student learning objectives. The curriculum set out in reference to the national and local curriculum is outlined in annual and semi annual programs based on the educational calendar.

2. Human Resources (HR), including principals, teachers, staff, other education personnel, students, parents, and community who have concern for the school.

Principals, teachers, staff, and education personnel are part of school personnel. To achieve the goal of education in schools, directed and continuous guidance and empowerment need to be carried out so personnel can perform the task professionally. This coaching and empowerment include academic, career, and welfare coaching. The service students get as customers started from enrollment, placement, coaching, until graduation. Schools as social institutions organized and owned by the community should meet the needs of the community. The relationship between school and community aims to build cooperation to facilitate education in accordance with the needs, expectations, and demands of society. School and community relations are a reciprocal communication process in an effort to instill the community's understanding of the needs of educational outcomes, to utilize the community's potential to help facilitate the implementation of education, and to encourage the interest and responsibility of the community to participate in advancing schools.

3. Physical Resources including buildings, rooms, equipment, educational props, study time, and physical appearance of the school.

Building, room, equipment, educational props, school physical appearance is a form of school infrastructure. Educational tools are tools that are directly used for teaching and learning activities. Educational infrastructure is a support facility for the implementation of educational activities, such as buildings, and other nonremovable objects.

4. Financial Resources is the overall school funding received from both the government and the community.

Funds for school activities should be managed appropriately because the source of school financial is usually limited. In addition, the school should be able to convince interested parties to be willing to support school funding to facilitate implementation of school programs.

All educational resources owned by schools is the main capital in conducting educational process which in accordance with educational goals that have been set. Proper utilization and management of educational resources are expected to support the process of professional education and become one of the strengths in education marketing strategy. Thus, produce qualified graduates and can meet the demand of business world, also in accordance with the demands of society for high-quality education.

\section{Education Communication}

Communication is the process of delivering messages from the messenger to the recipient. As stated by Murdock and Scutt quoted by Elearn Limited (2007: 2) in Iriantara, Y \& Usep S. (2013: 6) that communication is an exchange of information, verbally and through bodily expression, between two or more people in order to influence the occurrence of action, ideas or thoughts, at work, in leisure or community activities, or in individuals' domestic live[4]. 
School as an organization in carrying out its activities can not be separated from its communication system that has been established to support the organization's goals. Effective and productive educational communication is expected to help schools achieve communication impacts, for instance being able to attract students to school, facilitate the learning process of education, facilitate coordination in school management, and build knowledge, understanding, and community support for the existence of the school. In other words, the school as an organization can not be separated from the internal and external environment that affect the activities of the organization[1].

The internal environment of the school refers to the environment within the organization, such as organizational structure, culture, and resources. While the external environment of the school is the task environment and social environment associated with the activities of educational organizations, both micro and macro.

Educational communication can be divided into two, communication with the internal and external environment. The forms of education communication in an internal environment of the school are[4]:

a. Teacher and student communication. It is built in the form of communication learning, where teachers act as lecturers, moderators, mentors, managers, coordinators and innovators for students.

b. Communication principals, teachers, and other staff within the structure. It is formed based on hierarchical communication within the school's organizational structure, as a form of coordination to achieve the school vision through mission implementation or programs that have been established.

c. School and family communication. Family needs in term of communication with the school have undergone changes along with the increasing attention of parents to their children education. The information needed by the family from the school includes the achievement of the child, the child's behavior, the learning program, the child's performance appraisal mechanism, the financial and management, the extracurricular activities, the activities carried out by the school, and the rules of discipline and its consequences.

Educational communication with the school's external environment, including:

a. School and community communication. School communications to the community become the main task of school public relations. In general, the function of public relations according to NSPRA (2010) in Iriantara, Y \& Usep $\mathrm{S}$ (2013, pp. 121) is as a public relations counselor, communicating with internal and external public, media relations, establishing relationships with the community, especially in the preparation of school budget plan, preparing communications plans, conducting public relations studies, project image and schools marketing, create publications for teachers, staff and outstanding students, providing public information, providing public relations training for institution's personnel, and connecting schools and community.

b. School and government communication. The government is concerned with the implementation of education because of the strategic role of education in advancing the nation and actualizing the goals of the country. Communication and relationship built between schools and government are not only in the form of functional relationships between schools and education offices, but it also 
provides education policy direction in accordance with the expectations of educational institutions and government.

c. School and other stakeholders communications. Communication built between schools with other stakeholders such as other educational institutions, companies, industries, offices, and other institutions lead to the provision of support and mutual cooperation in the students learning process to have graduates who excel and quality $\{4\}$.

Educational communication is basically a key element to facilitate coordination and information delivery within the school (the internal environment of the school), from the school to its external environment, and to get reciprocity as a response from the recipient of information, both internal and external.

\section{Educational Marketing Strategy}

The education marketing that focuses on the concept of "marketing" emphasize on what the customer wants and the level of satisfaction. This approach is long-term oriented, where the meeting between the needs and wants of education customers becomes the main goal. This concept focuses on the needs and desires of customers who are formulated in the form of integrated marketing with the goal of achieving customer satisfaction[10].

To implement educational marketing, a strategy is needed to manage the resources of educational institutions, and how to inform educational customers in particular and society in general.

According to Kotler and Fox, marketing strategy (1995; pg. 163) is the institution's way of determining the superiority of market or program opportunities. They stated that:

"Marketing strategy is the selection of a target market, the choice of a

competitive position, and the development of an effective marketing mix

to reach and serve the chosen market[5]."

It can be concluded that the educational service marketing strategy is a way of an educational institution in determining the advantages of market opportunities or education service programs through an effective marketing mix. Effective marketing mix implemented by providing excellent education services in accordance with the needs of its customers, to built and maintain the brand image in society, and to achieve customer satisfaction.

The formulation of the marketing strategy of the educational institution involves a decision on[5]:

1. Program and institutional market at that time

2. New programs and future market opportunities.

3. Competitor analysis.

4. The position of institutions in relation to competitors.

5. Target market selection and marketing mix design.

Based on the above explanation, it can be concluded that the marketing of educational institutions includes the activities of designing the offering of educational services, meeting the needs and wants of the target market, using pricing effectively, communication, and distribution of education services to inform, motivate and serve the education market. 
To face competition among educational institutions, a school organization must have the right strategy for excellence. The excellence referred here relate to better and higher organizational performance, ability to create and offer superior customer value or better performance than others. For that, according to Rahayu, A. (2008, pp. 66-67) the advantage can be achieved with two basic strategies, namely:

1. Competitive strategy. This strategy will be effective if the organization has better resources (superior resources).

2. Cooperative strategy. This strategy will be effective if the organization has imperial resources[6].

And if it turns out that the organization has relatively similar resources, then the strategy choice consideration is more focused on market appeal.

\section{Optimization of Educational Resources and Communications in Educational Marketing Strategies}

In formulating a strategy, an organization needs goals, objectives, policies, programs, and decisions. All of these are formulated in the planning, the manner in which they are used, the patterns that are aligned with the organization's behavior, the positioning of the organization, and the way the organization views its position and role in its field. Deciding education marketing strategy, according to Haryanto, R \& Sylvia (2012) should be adjusted to the value of educational philosophy as a non-profit institution[1]. There are three important elements in the formulation of educational marketing strategies according to Kotler and Fox (1995) in Wijaya (2012: pp. 55):

1. Target market determination strategy. The aim is to identify specific market segments of educational services.

2. Market competition positioning strategy. Aims to identify the attributes of different educational institutions of other educational institutions, and to be the differentiator of its competitors.

3. Marketing mix strategy. The combination of elements owned by educational institutions that are managed in such a way as to be communicated and presented to educational customers[7].

Education has undergone rapid environmental changes and increasingly fierce competition. It needed appropriate marketing strategies which in accordance with the characteristics of educational institutions and the environment in order to be able to grow, develop and survive. For that, the resources management and communication should be applied in the formulation of educational marketing strategy starting from planning, implementation, until evaluation strategy.

\section{Target market determination strategy.}

Kotler and Fox (1995, pp. 163) called this stage as a stage of evaluating current offering and identifying opportunities or analysis of the education market[5]. The educational market is the target in conducting education that is identified with socially structured processes encompassing social, cultural, political, and implication of education activities.

The educational marketing environment is the place where the educational institutions should start their business in conducting education. The educational marketing environment according to Raya, M.K.F. (2016, p.33) is divided into two groups: 
a. Micro environment; is the market environment in the educational institutions, including those that supply resources, parties that help socialize education, parties who act as competitors, and education customers.

b. Macro environment; is the market environment in the scope of educational institutions, including those that supply resources, parties that help socialize education, parties who act as competitors, and education customers[8]

Adequate educational resources will support marketing manager in determining their marketing strategies. According to Lupiyoadi and Hamdani (2008) in Wijaya (2012; pg 58), if the educational resources are limited, then educational marketers will choose a concentrated marketing strategy[7]. While, if the educational resources are not limited, then marketing manager can choose marketing strategy with or without differentiator from its competitors.

In the process of setting target market targets, education managers identify and differentiate market segments based on educational resources owned by educational institutions and educational marketing environments. It was aimed so that the managers of educational institutions and policy makers can adapt the targeted marketing mix and not deviate or biased from the established purpose of the institution.

\section{Market competition positioning strategy.}

Market positioning is a way of putting the product into the minds of customers, organizing images and institutions in order to understand the position of the institution and create a different impression among its competitors. The creation of identities, images, and brands that differentiate educational institutions are another key factor in winning the hearts of education customers. Pelsmacker, Geuens, \& Bergh, (2003) in David, S \& Rasticova M (2011, p. 59) stated that the realization of 'position' is inseparable from the identity of educational institutions in which brands, products, distribution, and communication are processed between the holders[9].

Educational resources and communication become part of the factors that affect the position of educational institutions. According to Wijaya (2012: p 61), the factors that affect the organization are illustrated below:

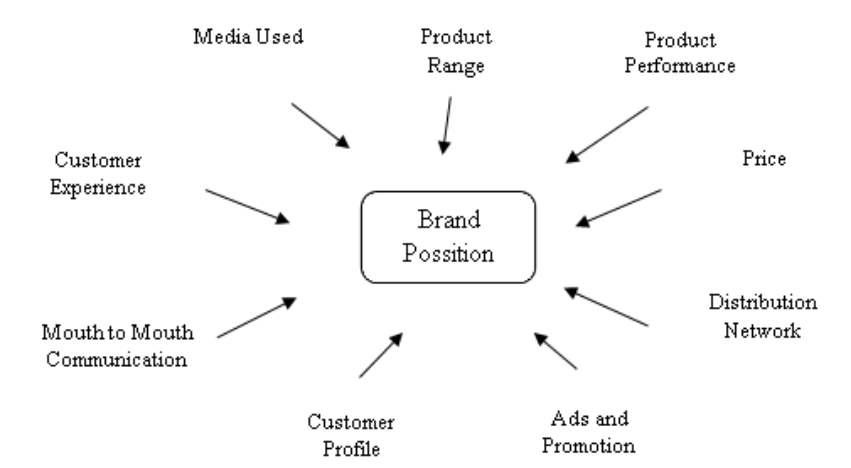

Figure 2. Factors influencing organization position

Management of educational resources and communication in the factors that optimally affect the organization's position make an educational institution has special characteristics that are different from its competitors. Effective and efficient utilization of the right communication channel and the empowerment of educational resources will support the creation of a particular impression for customers, which in turn will make educational institutions have the right 'position' in the hearts of customers. Managing 
educational resources optimally and distributing information about educational institutions through appropriate communication aims to have the competitiveness and have differences among other educational institutions.

\section{Marketing mix strategy.}

The results of the marketing of educational institutions are the satisfaction, loyalty, and welfare of the customers. Essentially, the education marketing aims to meet what the customer needs of education. To obtain the marketing strategy in accordance with the objectives of the educational institution, it needs the agency's ability to manage and utilize educational resources and communicate it effectively and efficiently. The final part of the preparation of the marketing strategy of the educational institution is the marketing mix as a more elaborate description of segmentation, targeting, and positioning in form of marketing program[8].

The elaboration of the utilization of educational resources and educational communication in the marketing mix is as follows:

a. Product

The educational product is a curriculum that includes educational program objectives, curriculum content, and a number of subjects, education that help create a competitive advantage. The curriculum policies used by educational institutions are in accordance with customer needs and communicated by the citizens of the school by prioritizing the quality of materials and the use of facilities that support[8].

b. Price

All amounts charged to a product as the exchange rate for the benefit of owning or using such services. In other words is the financing that must be spent by the service user to enjoy the services offered. According to Training Centre Department of National Education (2008) as quoted by Wijaya (2012, pp. 106) the price of services in the education is referred to as the cost of education, namely the rupiah value of all resources in the form of goods, sacrifices and money, issued for all educational activities[7].

Fund management undertaken by the financial department of educational institutions is primarily to support the implementation of teaching and learning activities adjusted to the priority scale that has been prepared in a financial planning, and regular monitoring and reporting of the use of funds.

c. Promotion

Promotions are made to market educational products. Promotion serves as a communication tool and a tool that affects education customers to make purchases of educational services as needed. Promotion for educational institutions is a form of marketing communication to publish, influence, persuade, remind, and convince customers of educational services offered by educational institutions.

Promotion is part of public relations tasks, where the main task is to communicate internally and externally about everything by utilizing the resources of education owned and aims to gain support and understanding of the efforts made by the institution.

\section{d. Human Resources /People}


It is a key element for the survival of educational institutions and as the key driver of the education system. Educational institutions should be directly involved with customers if they want to achieve optimal educational outcomes. The process of recruitment and selection, development, rewards, and performance appraisal of human resources in the educational institution has an impact on the quality of education in the institution. Effective educational communication and optimizing educational resources in communication become the main tools in the implementation of educational institution strategy.

e. Physical Evidence of Education Service

According to Alma, B \& Ratih H (2008, p. 155) physical evidence is an environment where educational institutions and students interact[10]. It is tangible elements that support educational performance or communication. The physical evidence includes school buildings, all infrastructure and facilities available in schools, including the library, laboratories, sports fields, etc.

f. Location of the Education Service (Place)

The location is where the education activities are carried out, including the interaction of educators, education personnel, and students. Strategic location, easy to access, and comfort place become the main consideration for education customers when choosing an educational institution. Utilization of land in the right location for educational operations makes high-value educational resources and make educational communication more effective and efficient.

g. Education Service Process

The Education Service process is a procedure, mechanism and a series of activities to deliver education services that involve all educational resources that exist in these educational institutions. Starting from teaching and learning activities, guidance and counseling, exams, graduation, and so forth. According to Booms and Bitner (1981) in Wijaya (2012, pp. 245), the service process is classified into five groups, namely policy, procedure, mechanization, employee engagement, and flow of activities[7]. Management of educational resources and educational communication will have a direct impact on the range of activities in the education services process. If management is running optimally, effectively, and efficiently, then the education service process can produce qualified and competitive graduates in the community

\section{CONCLUSION}

Quality of education is the primary consideration for education customers to choose educational institutions. The quality of education will be known by community when the educational institution proved it by the graduation's qualities, and sound this acievement through a good communications. The roles of education marketing are to make educational institutions are known and become the people's choice. The high interest and increased customer loyalty of education are one of the indications of successful implementation of the marketing strategy of educational institutions. Effective education marketing strategies can be seen from the ability of educational institutions to optimally identify, utilize, and manage educational resources and 
communication as the main capital, starting from the planning preparation, implementation, and evaluation.

\section{REFERENCE}

1. Haryanto, Rudy \& Sylvia Rozza. 2012. Pengembangan Strategi Pemasaran dan Manajemen Hubungan Masyarakat dalam peningkatan Peminat Layanan Pendidikan. Jurnal ekonomi dan Bisnis, Vol. 11, No. 1, Juni 2012: 27-34. Online accessed at August 25, 2016 at http://www.jurnalpnj.com

2. UU RI No. 4 Tahun 1982. Ketentuan-Ketentuan Pokok Pengelolaan Lingkungan Hidup. Online accesssed at May 1, 2017 on http://blh.jatimprov.go.id/index.php?option=com.docman\&task=doc.view \& gid=40\& $\underline{\text { temid }=145}$

3. Hermawan, Ruswandi. 2010. Pengembangan Sumber Daya Sekolah. Jurnal Pendidikan Dasar No. 13. April 2010. Online accessed at May 1, 2017 on http://file.upi.edu/Direktori/JURNAL/PENDIDIKAN_DASAR/ Nomor_13April_2010/Pengembangan_Sumber_Daya_Sekolah-Ruswandi_Hermawan.pdf

4. Iriantara, Yosal \& Usep Syaripudin. 2013. Komunikasi Pendidikan. Bandung:PT. Rosdakarya Offset.

5. Kotler, Philip \& Karen F.A. Fox. 1995. Strategic Marketing for Educational Institution. New Jersey: Prentice-Hall, Inc.

6. Rahayu, Agus. 2008. Strategi Meraih Keunggulan Dalam Industri Jasa Pendidikan (Suatu Kajian Manajemen Strategik). Book of Manajemen Corporate dan Strategi Pemasaran Jasa Pendidikan. Bandung: Alfabeta.

7. Wijaya, David. 2012. Pemasaran Jasa Pendidikan "Mengapa Sekolah Memerlukan Marketing”. Jakarta: Salemba Empat.

8. Raya, M.K.F. 2016. Marketing Jasa Di Institusi Pendidikan (Analisis Pemasaran dalam Pendidikan). Jurnal Falasifa, vol. 7 nomor 1 tahun 2016. Online accessed at May 1, 2017 on http://ejournal.staifas.ac.id/index.php/ falasifa/article/download/2/2

9. David, Schuller \& Rasticova Martina. 2011. Marketing Communications Mix of Universities - Communication With Students in an Increasing Competitive University Environment. Journal of Competitiveness. Issue 3/2011. P58-71. Online accessed at April 27, 2017 on http://cjournal.cz/files/67.pdf

10. Alma, Buchari \& Ratih Hurriyati. 2008. Manajemen Corporate dan Strategi Pemasaran Jasa Pendidikan. Bandung: Alfabeta. 